\title{
A new species of the orb-weaving spider Mangora from Brazil (Araneae: Araneidae)
}

\author{
Karina P. Santos \& Adalberto J. Santos
}

Departamento de Zoologia, Instituto de Ciências Biológicas, Universidade Federal de Minas Gerais. Avenida Antonio Carlos 6627, 31270-901 Belo Horizonte, MG, Brazil. E-mail: falecomaka@hotmail.com; oxyopes@yahoo.com

\begin{abstract}
A new species, Mangora ouropreto sp.nov., is described and illustrated based on male and female specimens from Ouro Preto, state of Minas Gerais, Brazil. Males of the new species can be distinguished by an anterior projection on the terminal apophysis, which is wider apically and has a serrated edge. Females resemble those of M. chiguaza Levi, 2007 in the shape of epigynum, but differ in the smaller and posteriorly directed scape.
\end{abstract}

KEY WORDS. Taxonomy, Itacolomi, Neotropical region.

\begin{abstract}
Mangora O.P.-Cambridge, 1889 is one of the most distinctive groups among orb-weaving spiders. It differs from most other genera in the following characters: pars thoracica higher than pars cephalica, pedicel attached to the middle of anterior third of abdomen, instead of attached apically; and in a unique set of long, feathery trichobothria on the anterior surface of the third tibia (Levi 2007). The genus is distributed predominantly in the New World, with one species in Europe, 11 in Asia (mostly China), one in Africa and 179 in the Americas (Platnick 2010). The most recent study on this genus was a revision of the South American species (Levi 2007). The results of that study showed that Mangora is among the most diverse orb-weaving spider genera in the subcontinent. Of the 142 species included in Levi's contribution (2007), 127 were new. Considering the scarcity of material in South American spider collections, several unknown species may be still collected and described. In this study we describe a new species of Mangora, based on specimens collected during a spider diversity inventory in southeastern Brazil.
\end{abstract}

\section{MATERIAL AND METHODS}

The specimens examined were collected in the Parque Estadual do Itacolomi (Ouro Preto, state of Minas Gerais), an area of deciduous Atlantic Forest with a seasonal climate. Local weather varies from dry and cold between May and September to wet and warm from October to April (for more details, see Dutra et al. 2005). The material was collected using beating trays in two areas of secondary, seasonal forest, and two Eucalyptus plantation areas with regenerating undergrowth. All the material examined is deposited in the Coleções Taxonômicas da UFMG, Belo Horizonte (UFMG, curator A.J. Santos). Specimens were examined and photographed with a Leica DFC500 digital camera attached to a Leica M205C stereoscopic microscope. Pic- tures taken in several focal planes were assembled in multifocal images with the software Leica Applications Suite Vers. 3.3.0 (Leica Inc.). Morphological terminology and description follow LeVI (2007). All measurements are in millimeters.

\section{TAXONOMY}

\section{Mangora ouropreto sp.nov.}

Figs 1-5

Type specimens. Holotype: male from Parque Estadual do Itacolomi $\left(20^{\circ} 22^{\prime} \mathrm{S}, 43^{\circ} 32^{\prime} \mathrm{W}\right)$, Ouro Preto, state of Minas Gerais, Brazil, 11-13. IV. 2008, K.P. Santos et al. leg., deposited in UFMG 2368. Paratypes: male and female from the same locality and date, deposited in UFMG 2140; female from the same locality, 2-4.XI.2007, deposited in UFMG 2048.

Diagnosis. Males of Mangora ouropreto sp. nov. can be distinguished from those of other species of the genus by an anterior, wider apically projection in the terminal apophysis (Fig. 3). The female epigynum resembles that of $M$. chiguaza Levi, 2007 in the slightly subtriangular scape in ventral view (see Levi 2007: fig. 24), but differs in the smaller and posteriorly directed scape (Figs 4-5).

Description. Male (holotype). Carapace (Fig. 1), chelicerae, labium, endites, sternum and legs homogeneously yellow. Dorsum of abdomen pale yellow, with sparse and irregular white spots and with three pairs of anterior lateral brown spots. Sides and venter homogeneously pale yellow. Total length 2.7 , carapace 1.1 long, 0.9 wide. First femur 1.0, patella + tibia 1.0, metatarsus 0.9 , tarsus 0.5 . Second patella + tibia 1.2 , third 0.6 , fourth tibia missing.

Female (paratype). Color pattern as in male, but lighter (Fig. 2). Total length 2.7, carapace 1.0 long, 0.8 wide. First femur 1.0 , patella + tibia 1.1 , metatarsus 0.6 , tarsus 0.5 . Second patella + tibia 1.2 , third 0.7 , fourth 1.2 . 

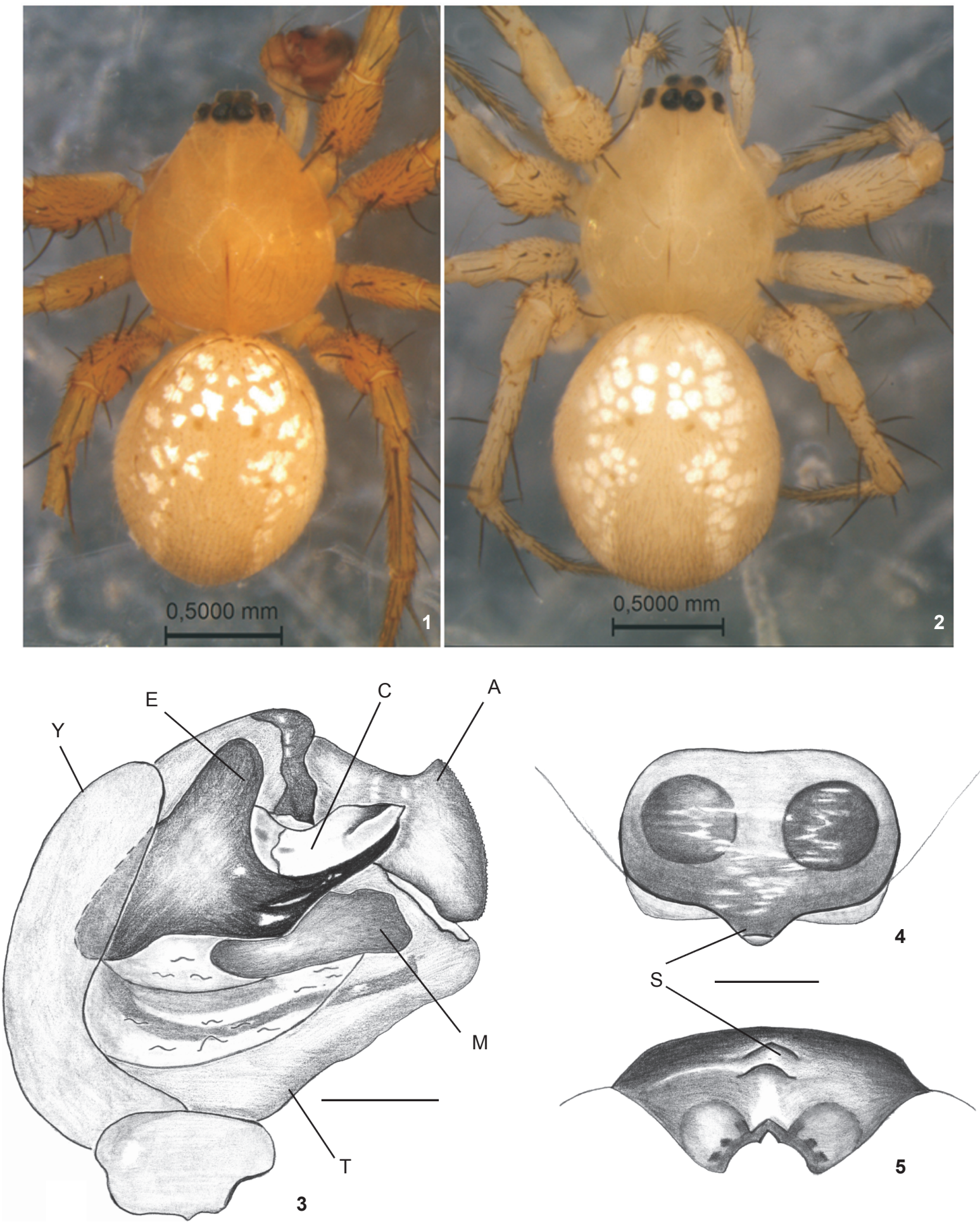

Figures 1-5. Mangora ouropreto sp. nov. (1-2) Habitus, dorsal view: (1) male, holotype; (2) female, paratype, UFMG 2140; (3) male palp, holotype, mesal view; (4) epigynum, paratype, UFMG 2140, ventral view; (5) same, posterior view. (A) Terminal apophysis, (C) conductor, (E) embolus, (M) median apophysis, $(\mathrm{S})$ scape, $(\mathrm{T})$ tegulum, $(\mathrm{Y})$ cymbium. Scale bars: $0.5 \mathrm{~mm}$. 
Variation. The female abdomen can have ventral white spots and a anterior dorsal gray spot. Total length: males $(\mathrm{N}=$ 2) 2.5-2.7, females $(\mathrm{N}=3)$ 2.5-2.7; carapace width: males 1.11.3, females 1.0-1.3.

Additional material examined. BraziL, Minas Gerais: Ouro Preto (Parque Estadual do Itacolomi, $20^{\circ} 22^{\prime} \mathrm{S}, 43^{\circ} 32^{\prime} \mathrm{W}$ ), 1113.IV.2008, 1\#f (UFMG 3869).

Etymology. The specific epithet is a noun in apposition taken from the type locality.

\section{ACKNOWLEDGEMENTS}

We thank the Instituto Estadual de Florestas/MG and the director of the Parque Estadual do Itacolomi, Adalberto Vieira de Mello Matos, for issuing collecting permits and for logistical support in our field study. We are also indebted to several colleagues from our lab and from Universidade Federal de Ouro Preto for help with field work, and to two anonymous referees for suggestions on the manuscript. K.P. Santos received a PIBIC/
CNPq/UFMG fellowship and A.J. Santos was financially supported by grants from CNPq (Proc. 472976/2008-7 and 300498/ 2009-8) and Instituto Nacional de Ciência e Tecnologia dos Hymenoptera Parasitóides da Região Sudeste Brasileira (www.hympar.usfcar.br).

\section{LITERATURE CITED}

Dutra, V.F; M.C.T Messias \& F.C.P. Garcia. 2005. Papilionoideae (Leguminosae) nos campos ferruginosos do Parque Estadual do Itacolomi, Minas Gerais, Brasil: florística e fenologia. Revista Brasileira de Botânica 28: 493-504.

Levi, H.W. 2007. The Orb Weaver Genus Mangora in South of America (Araneae, Araneidae). Bulletin of the Museum of Comparative Zoology Harvard University 159: 1-144.

Platnick, N.I. 2010. The Word Spider Catalog, version 11.0. American Museum of Natural History, available online at: http://research.amnh.org/entomology/spiders/catalog/ index.html [Accessed: 1.VIII.2010).

Submitted: 22.IX.2010; Accepted: 02.XII.2010.

Editorial responsibility: Antonio D. Brescovit 